\title{
PENGGUNAAN TEPUNG LIMBAH LABU KUNING (Cucurbita moschata) DALAM PAKAN AYAM PETELUR TERHADAP KUALITAS INTERNAL TELUR AYAM RAS
}

\author{
Devi R. Utiah, Fredy J. Nangoy, Lucia Lambey, Wapsiaty Utiah* \\ Fakultas Peternakan Universitas Sam Ratulangi Manado, 95115
}

\begin{abstract}
ABSTRAK
Penelitian ini bertujuan untuk mengetahui pengaruh penggunaan tepung limbah labu kuning/waluh (cucurbita moschata) dalam pakan ayam petelur terhadap indeks putih telur, indeks kuning telur, dan warna kuning telur. Penelitian ini menggunakan 100 ekor ayam ras petelur umur 42 minggu. Penelitian ini dilakukan di Laboratorium Teknologi Hasil Ternak, Fakultas Peternakan Universitas Sam Ratulangi. Variabel yang diamati terdiri dari indeks putih telur, indeks kuning telur dan warna kuning telur. Metode yang digunakan adalah rancangan acak lengkap yang terdiri dari lima perlakuan dan 5 ulangan, Perlakuan yang diberikan yaitu penggantian tepung limbah labu kuning, dengan masingmasing perlakuan adalah $\mathrm{R} 0=$ Ransum dasar tanpa menggunakan tepung limbah labu kuning, $\mathrm{R} 1$ = Ransum dasar 98\% $+2 \%$ tepung limbah labu kuning, R2 = Ransum dasar $96 \%+4 \%$ tepung limbah labu kuning, R3 = Ransum dasar 94\% + 6 $\%$ tepung limbah labu kuning, R4 = Ransum dasar $92 \%+8 \%$ tepung limbah labu kuning. Hasil analisis menunjukkan bahwa penggunaan tepung limbah labu kuning pada level $2 \%, 4 \%, 6 \%$, dan $8 \%$ dalam ransum memberikan pengaruh tidak nyata $(\mathrm{P}>0.05)$ terhadap indeks putih telur, indeks kuning telur, dan warna kuning telur. Kesimpulannya adalah penggunaan tepung limbah labu kuning sampai level $8 \%$ dalam pakan ayam petelur
\end{abstract}

*Korespondensi (corresponding author)

Email : wapsiatyutiah@yahoo.co.id memberikan hasil yang sama terhadap indeks putih telur, indeks kuning telur dan warna kuning telur.

Kata kunci : limbah labu kuning (Cucurbita moschata), telur, ayam petelur

ABSTRACT
UTILIZATION OF Y YELLOW
PUMPKIN WASTE PRODUCT
(Cucurbita moschata) IN RATION OF
LAYING HENS ON INTERNAL EGG
CHARACTERISTICS. The aim of this
research is to know the effect of the use of yellow pumpkin flour/waluh (cucurbita moschata) in laying chicken feed against egg white index, egg yolk index, and yolk color. This study used 100 laying chickens aged 42 weeks. This research was conducted at Animal Product Technology Laboratory, Faculty of Animal Husbandry of Sam Ratulangi University. The observed variables consisted of egg white index, yolk index and yolk color. The method used is a complete randomized design consisting of five treatments and 5 replications. The treatment is the replacement of yellow pumpkin flour, with each treatment is $\mathrm{R} 0=$ Basic ration without using yellow pumpkin flour, R1 = Ration $98 \% 2 \%$ yellow pumpkin flour, R2 $=$ base ration $96 \%+4 \%$ yellow pumpkin flour, $\mathrm{R} 3=$ base ration $94 \%+6 \%$ yellow pumpkin flour, $\mathrm{R} 4=$ base ration $92 \%+$ $8 \%$ yellow pumpkin flour. The results showed that the use of yellow pumpkin flour at level 2\%, 4\%,6\%, and $8 \%$ in the ration gave no significant effect $(\mathrm{P}>0.05)$ on egg white index, yolk index, and yolk color. The conclusion is that the use of pumpkin flour waste up to $8 \%$ level in laying chicken feed gives the same result 
to egg white index, yolk index and yolk color.

Key words: Pumpkin waste, egg, hen.

\section{PENDAHULUAN}

Usaha peternakan ayam merupakan sector kegiatan yang paling cepat dan efisien untuk menghasilkan bahan pangan hewani yang bergizi. Alternatif yang dapat dilakukan yaitu dengan memelihara ayam petelur yang dapat memberikan keuntungan ganda yaitu telur dan daging. Beternak ayam petelur yang dijadikan lading usaha mempunyai makna bahwa usaha peternakan yang dilakukan harus benar benar dapat dijadikan andalan usaha bagi pemiliknya, baik sebagai penghasilan tambahan maupun mata pencarian utama. Telur merupakan bahan pangan sempurna, karena mengandung zat gizi yang dibutuhkan untuk makhluk hidup seperti protein, lemak, vitamin dan mineral dalam jumlah cukup. Telur mengandung protein bermutu tinggi karena mengandung susunan asam amino esensial lengkap sehingga telur dijadikan patokan dalam menentukan mutu protein berbagai bahan pangan. Telur merupakan produk unggas yang cukup potensial dan merupakan bahan pangan yang memiliki kandungan gizi yang cukup sempurnah karena mengandung zat-zat gizi yang lengkap dan muda dicerna (Abbas, 1989).Menurut Sudaryani (2003) kandungan gizinya merupakan perpaduan yang serasi dan seimbang antara protein, energi, vitamin, mineral dan air.Telur merupakan salah satu jenis pangan hewani utama bagi manusia diseluruh dunia (Gonzales Esquerra et al., 2000; Milinsketal., 2003; Carrillo - Dominguesetal., 2005). Kualitas telur menjadi perhatian penting untuk konsumen. Beberapa faktor yang mempengaruhi karakteristik dari telur unggas adalah zat makanan dan lingkungan (Weatherup, 1980). Faktor zat makanan diantaranya yaitu kandungan kalsium (ca), energi dan pakan. Labu kuning merupakan salah satu jenis labu yang cukup populer di Indonesia meski buah ini berasal dari Mexico Tengah dan menyebar ke Benua Amerika. Di Indonesia labu kuning memiliki nama yang cukup dikenal yaitu waluh, sedangkan secara ilmiah labu kuning disebut Cucurbita moschata (Widayati, 2000). Labu kuning termasuk salah satu jenis tanaman makanan yang memiliki kandungan gizi yang cukup tinggi dan cukup lengkap, karena mengandung protein, lemak, karbohidrat, Vitamin A, B, C, magnesium, Fosfor dan kalori (Sudarto,1993). Limbah labu kuning merupakan hasil dari sisa buangan buah labu kuning utuh yang masih bisa dimanfaatkan misalnya dalam hal penelitian dan dapat menjadi sumber gizi yang sangatpotensial dan ekonomis. Karena limbah labu kuning tidak bersaing 
dengan manusia yang dibutuhkan manusia hanya dagingnya tidak dengan limbahnya yang terdiri dari bagian kulit, biji dan serat berlendir yang menyelimuti biji labu kuning tersebut.

Dari pembahasan diatas maka telah dilakukan penelitian dengan judul

"Penggunaan Tepung Limbah Labu Kuning (Cucurbita Moschata) Dalam Pakan Ayam Petelur Terhadap Kualitas Internal Telur Ayam Ras" yang diharapkan dapat menghasilkan telur dengan kualitas yang lebih baik sehingga dapat memenuhi kebutuhan konsumen.

\section{MATERI DAN METODE PENELITIAN}

Materi yang digunakan pada penelitian ini adalah ayam ras petelur fase layer umur 42 minggu dari jenis MB 402 sebanyak 100 ekor. Kandang yang digunakan adalah kandang baterai dengan ukuran $37 \times 40 \times 30 \mathrm{~cm}$ yang terdiri dari 25 unit dan setiap unit kandang ditempati 4 ekor ayam. Peralatanyang digunakan yaitu timbangan digital, calliper dan yolk colour fun.Penelitian ini di laksanakan sejak tanggal 26 Agustus s/d 29 Oktober 2015 yang terdiri dari 7 hari masa pendahuluan dan 56 hari masa pengambilan data.
Prosedur penelitian yaitu: kandang yang akan digunakan terlebih dahulu disucihamakan yaitu dibersihkan darikotoran dengan menggunakan detergen, air, dan kemudian didesinfektan menggunakan air kapur. Setiap pagi dan sore hari wadah air minum dibersihkan dan diisi dengan air minum yang baru.

Ransum perlakuan yang diberikan pada penelitian ini disusun setiap hari berdasarkan kebutuhan ayam petelur sebanyak $125 \mathrm{~g} /$ ekor/hari dan diberikan sebanyak 2 kali yaitu pada pagi hari pukul 06.30 sebanyak $50 \%$ dan sisanya pada siang hari pukul 14.00 dengan protein $17 \%$ dan energi $2700 \mathrm{Kkal}$ dengan penambahan tepung limbah labu kuning sebanyak $2 \%$, $4 \%$, 6\% dan $8 \%$. Pada setiap perlakuan diberikan ransum dan air minum secara ad libitum, mengontrol serta penambahan pakan dan air minum dilakukan pada pagi, siang dan sore hari. Komposisi bahan pakan ransum kontrol dan ransum percobaan dapat dilihat pada Tabel 2 dan 3, sedangkan untuk komposisi zat-zat makanan ransum percobaan dapat dilihat pada Tabel 4 dan komposisi zat zat dan bahan makanan ransum percobaan dilihat pada Tabel 1. 
Tabel 1. Komposisi Zat-zat dan Bahan Makanan Ransum Percobaan

\begin{tabular}{|c|c|c|c|c|c|c|}
\hline Bahan makanan & $\begin{array}{c}\text { Protein } \\
(\%)\end{array}$ & $\begin{array}{c}\text { Lemak } \\
(\%)\end{array}$ & $\begin{array}{c}\text { Seratkasar } \\
(\%)\end{array}$ & $\begin{array}{l}\mathrm{Ca} \\
(\%)\end{array}$ & $\begin{array}{c}\mathrm{P} \\
(\%)\end{array}$ & $\begin{array}{c}\mathrm{ME} \\
(\mathrm{Kkal}) / \mathrm{kg}\end{array}$ \\
\hline Jagung Kuning** & 8.8 & 3.9 & 2 & 0.02 & 0.28 & 3350 \\
\hline Dedak Halus** & 12 & 13 & 12 & 0.12 & 0.5 & 1630 \\
\hline Tepung Ikan** & 60 & 9 & 1 & 5.5 & 0.3 & 2830 \\
\hline $\mathrm{CaCO}_{3} * * *$ & 0 & 0 & 0 & 29.4 & 0 & 0 \\
\hline Konsentrat Cal 9.36*** & 29 & 10 & 7 & 3 & 2 & 2600 \\
\hline T. Limb. Labu Kuning* & 23.14 & 14.59 & 17.48 & 0.76 & 0.75 & 3882.4 \\
\hline
\end{tabular}

Tabel2. Komposisi Bahan Pakan Ransum Kontrol

\begin{tabular}{lrrrrr} 
BahanMakanan & Jagung & Dedak & TepungIkan & $\mathrm{CaCO}_{3}$ & Konsentrat \\
\cline { 2 - 6 } & \multicolumn{5}{c}{$(\%)$} \\
Jumlah (100) & 50 & 12 & 7 & 5 & 26 \\
\hline
\end{tabular}

Tabel 3. Komposisi Bahan Pakan Ransum Percobaan

\begin{tabular}{lccccc}
\hline \multirow{2}{*}{ Bahan Makanan } & $\mathrm{R}_{0}$ & $\mathrm{R}_{1}$ & $\mathrm{R}_{2}$ & $\mathrm{R}_{3}$ & $\mathrm{R}_{4}$ \\
\cline { 2 - 6 } & 100 & 98 & 96 & 94 & 92 \\
\hline $\begin{array}{l}\text { Ransum Basal } \\
\text { Kumbah Labu }\end{array}$ & 0 & 2 & 4 & 6 & 8 \\
\hline Total & 100 & 100 & 100 & 100 & 100 \\
\hline
\end{tabular}

Tabel 4. Komposisi Zat-zat Makanan Ransum Percobaan

\begin{tabular}{lccccc}
\hline Komposisi & Zat- & \multicolumn{5}{c}{ Persentase $(\%)$} \\
\cline { 2 - 6 } zatMakanan & $\mathrm{R}_{0}$ & $\mathrm{R}_{1}$ & $\mathrm{R}_{2}$ & $\mathrm{R}_{3}$ & $\mathrm{R}_{4}$ \\
\hline Protein & 17.58 & 17.69 & 17.80 & 17.91 & 18.02 \\
Lemak & 4.33 & 4.54 & 4.74 & 4.95 & 5.15 \\
Serat kasar & 6.74 & 6.95 & 7.17 & 7.38 & 7.60 \\
Ca & 2.66 & 2.62 & 2.58 & 2.55 & 2.51 \\
P & 0.74 & 0.74 & 0.74 & 0.74 & 0.74 \\
ME (Kkal) & 2745.00 & 2767.75 & 2790.50 & 2813.24 & 2835.99 \\
\hline
\end{tabular}

Selanjutnya proses pengolahan tepung limbah labu kuning terlihat oada gambar 1 


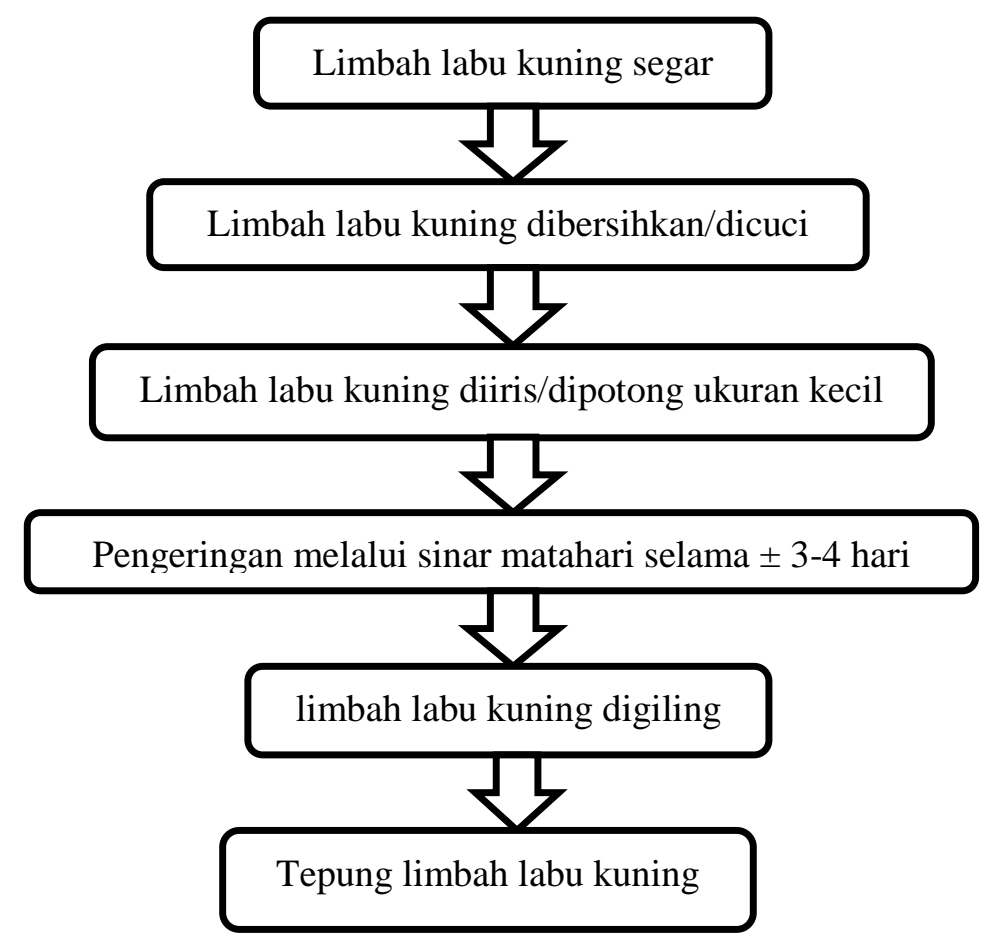

Gambar 1.Skema Pembuatan Tepung Limbah Labu Kuning.

Pengambilan telur dilakukan pada pagi hari pukul 10.00 WITA dan sore hari pukul $16.00 \quad$ WITA, sedangkan pengambilan telur untuk analisis indeks putih telur, indeks kuning telur dan warna kuning telur dilakukan seminggu sekali setiap hari Kamis selama periode penelitian. Setiap perlakuan diambil 1 butir telur sebagaia sampel untuk dianalisis di Laboratorium Teknologi Hasil Ternak, Fakultas Peternakan Universitas Sam Ratulangi.

Metode yang digunakan pada penelitian ini adalah rancangan acak lengkap (RAL) dengan 5 perlakuan dan 5 ulangan menurut Steel and Torrie (1991). Masing-masing perlakuan yaitu : R0 = Ransum dasar tanpa menggunakan tepung limbah labu kuning, R1 = Ransum dasar
$98 \%+2 \%$ tepung limbah labu kuning, R2 $=$ Ransum dasar $96 \%+4 \%$ tepung limbah labu kuning, R3 = Ransum dasar 94\% + 6 $\%$ tepung limbah labu kuning, R4 = Ransum dasar $92 \%+8 \%$ tepung limbah labu kuning.

Variabel yang diamati dalam penelitian ini adalah sebagai berikut

1. Indeks putih telur (Muchtadi dan Sugiyono, 1992).

Index putih telur $=\frac{\text { tinggi putih telur }}{\text { diameter putih telur }}$

2. Indeks kuning telur (Muchtadi dan Sugiyono, 1992).

Indeks kuning telur $=$ diameter kuning telur

3. Warna kuning telur dengan metode dari North dan Bell, (1984) 


\section{HASIL DAN PEMBAHASAN}

\section{Pengaruh Perlakuan Terhadap Indeks Putih Telur}

Dapat diketahui rata-rata indeks putih telur yang diperoleh dari perlakuan R0, R1, R2, R3 dan R4 secara berturut-turut adalah 0,0825; 0,0833 ;0,0768 ; 0,0759 dan 0,0758. Untuk mengetahui pengaruh dari perlakuan yang diberikan maka dilakukan analisis statistik.

Hasil analisis statistik menunjukkan bahwa perlakuan penggunaan tepung limbah labu kuning sampai level $8 \%$ tidak memberikan pengaruh nyata $(\mathrm{P}>0,05)$ terhadap indeks putih telur. Keadaan ini dimungkinkan karena kandungan protein dalam masing-masing pakan perlakuan pada penelitian tidak jauh berbeda, hal ini yang memungkinkan penggunaan tepung limbah labu kuning tidak memberikan pengaruh yang nyata terhadap nilai indeks putih telur.

Hasil dari penelitian ini masih lebih rendah yaitu 0,0752-0,0831 dengan indeks putih telur menurut (Buckle, 1987) yang berada pada kisaran 0,09-0,12. Indeks putih telur juga biasa menurun karena penyimpanan dan pemecahan ovomucin yang dipercepat pada $\mathrm{pH}$ yang tinggi. (Harmayanda,2016).

Indeks putih telur ditentukan oleh tinggi putih telu rkental dan diameternya. Indeks putih telur dipengaruhi oleh protein pakan. Protein Pakan akan mempengaruhi viskositas telur yang mencerminkan kualitas internal telur, selanjutnya dapat mempengaruhi indeks putih telur. (Yuliansyah, 2015).

\section{Pengaruh Perlakuan Terhadap Indeks} Kuning Telur

Dapat diketahui rata-rata indeks kuning telur yang di peroleh dari perlakuan R0, R1, R2, R3 dan R4 secara berturut turut adalah0,409;0,431;0,432 ; 0,423 dan 0,419. Untuk mengetahui pengaruh perlakuan maka dilakukan analisis statistik. Hasil analisis statistik menunjukkan bahwa perlakuan penggunaan tepung limbah labu kuning dalam ransum sampai level $8 \%$ tidak memberikan pengaruh nyata $(\mathrm{P}>$ 0,05) terhadap indeks kuning telur. Tidak berbedanya hasil analisis statistik dapat dimungkinkan karena kandungan zat-zat makanan dalam ransum tidak jauh berbeda.

Berat kuning telur dipengaruhi oleh perkembangan ovarium, berat badan ayam, umur saat mencapai dewasa kelamin, kualitas dan kuantitas pakan, penyakit, lingkungan dan konsumsi pakan (Tugiyanti dan Iriyanti 2012). Nilai indeks kuning telur yang diperoleh dari hasil penelitian ini tergolong normal yaitu $0,409-0,432$. Penelitian yang dilakukan (Argo.,2013) melaporkan bahwa indeks kuning telur yang baru bervariasi antara 0,30 - 0,50. Indeks kuning telur dipengaruhi oleh protein, lemak, dan asam amino esensial 
Tabel 5. Nilai Rataan Variabel Yang Diamati.

\begin{tabular}{llllll}
\hline \multirow{2}{*}{ Variabel } & \multicolumn{5}{c}{ Perlakuan } \\
\cline { 2 - 6 } & $\mathrm{R} 0$ & $\mathrm{R} 1$ & $\mathrm{R} 2$ & $\mathrm{R} 3$ & $\mathrm{R} 4$ \\
\hline indeks putih telur & 0,0825 & 0,0833 & 0,0768 & 0,0759 & 0,0758 \\
indeks kuning telur & 0,4063 & 0,4312 & 0,4328 & 0,4285 & 0,4166 \\
warna kuning telur & 9,525 & 9,850 & 9,275 & 9,575 & 9,7750 \\
\hline
\end{tabular}

yang terkandung dalam pakan. Faktor yang mempengaruhi indeks kuning telur antara lain ukuran telur, lama penyimpanan, suhu tempat penyimpanan, kualitas membrane evitelin, dan nutrisi pakan. Tuti (2009) juga menambahkan bahwa kualitas kuning telur tergantung pada besar kuning telur.

\section{Pengaruh Perlakuan Terhadap Warna Kuning Telur}

Hasil penelitian menunjukkan ratarata warna kuning telur yang diperoleh dari perlakuan R0, R1, R2, R3 dan R4 secara berturut-turut adalah 9,$525 ; 9,850 ; 9,275$; 9,575 dan 9,775. Untuk mengetahui pengaruh perlakuan maka dilakukan analisis statistik. Hasil analisis statistik menunjukkan bahwa perlakuan penggunaan tepung limbah labu kuning dalam ransum sampai level $8 \%$ tidak memberikan pengaruh nyata $(\mathrm{P}>0,05)$ terhadap warna kuning telur. Tidak berbedanya hasi lanalisis statistik dalam penelitian ini dimungkinkan karena tepung limbah labu kuning dalam ransum dinamakan dengan Beta karoten sebagai pigmen warna kuningoranye dalam buah labu kuning adalah sama. Skor warna kuning telur yang diperoleh dari penelitian berkisar antara 9,275 - 9,85. Nilai ini masih berada dalam kisaran warna kuning telur yang disukai konsumen. Menurut Stadellman (1995) warna kuning telur yang baikberada pada kisaran 7 - 12. Amrullah (2004) menyatakan bahwa laju produksi telur menyebabkan keragaman warna kuning telur ketika produksi telur meningkat, xantofil dalam ransum menyebar kebanyak kuning telur sehingga warna kuning telur menurun dan sebaliknya. Jenis dan jumlah karatenoid yang ada dalam kuning telur tergantung dalam jumlahnya dalam pakan yang dikonsumsi ayam. Karatenoid memberikan warna kuning pada kuning telur. (Surai, 2000).Menurut Sahara (2010) warna kuning telur dipengaruhi oleh zat-zat yang terkandung dalam pakan seperti xantofil, beta karoten, klorofil dan cytosan. Pigmen pemberian warna kuning telur yang ada dalam pakan secara fisiologis akan diserap oleh organ pencernaan usus halus dan diedarkan keorgan yang membutuhkan. Warna kuning telu rmerupakan salah satu karakteristik yang sangat penting dalam penentuan kualitas telur oleh konsumen. 
Warna kuning telur dipengaruhi oleh pigmen karoten (Kang, 2003).

\section{KESIMPULAN}

Berdasarkan hasil analisis data dan pembahasan untuk semua variable pada penelitian ini, maka dapat Disimpulkan bahwa penggunaan tepung limbah labu kuning sampai $8 \%$ dalam pakan ayam petelur tidak mempengaruhi kualitas internal telur ayam ras.

\section{DAFTAR PUSTAKA}

Abbas M.H. 1989. Pengelolaan Produk Unggas. Jilid 1. Universitas Anadalas. Padang.

Amrullah I. K 2004. Nutrisi Ayam Petelur satu Gunung Budi Bogor.

Argo, L.B., Tristiarti., 1. Mangisah. 2013. Kualitas fisik telur ayam arab petelur fase 1 dengan berbagai level azolla microphilla. Journal of Animal Agriculture 2 (1) : 9-10.

Buckle, A.K., A.R. Edwards, G.H. Fleet dan M. Wotton. 1987. Ilmu Pangan. Universitas Indonesia Jakarta.

Gonzales.E. R, S.Leeson S. 2000 Effect of feeding hens regularor deodorizen menhaden oil on production parameters, yolk fatty acid profile, and sensory quality of eggs. Poultry Sci.;79:1597-1602.

Harmayanda P. O.A., Dj. Rosidi., O.Sjofjan 2016. unis pakan komersial ayam petelur. Indonesian Journal of Enviranment and Sustainable Development 7(1) : 25-32

Kang, D. K., S. I. Kim, C. H. Cho, Y. H. Kang,Yim, and H. S. Kim. 2003. use of lycopene, antioxidant carotenoid, in laying hens for egg yolk pigmentation. Asian-Aust. J. Anim..Sci. 16 (12): 1799-1803.

Muchtadi T.R dan Sugiyono. 1992. Ilmu Pengetahuan Bahan Pangan. Petunjuk Laboratorium. Departemen Pendidikan dan Kebudayaan Direktorat Jenderal Pendidikan Tinggi Pusat Antar Universitas Pangan dan Gizi, Institut Pertanian Bogor.

North, M. O. And D. D. Bell. 1984 Commercial Chicken Production Manual. 3rd Ed. The Avi Publishing Compani, Inc. Wesport, Connecticut

Sahara. 2010. Penggunaan Kepala Udang Sebagai Sumber Pigmen Kesin Dalam Pakan Ternak. Agrinale I ( I ) :31-35

Stadellman 1995 Egg Science and Tecnology FaurtEd Food Product Press. An Imprint of the Haworth Press Inc.New York London.

Sudarto Y, 1993, Budidaya Waluh, Kanisius, Yogyakarta.

Sudaryani, T. dan H. Santoso. 2003. Pembibitan Ayam Ras. Cetakan keVII. Penebar Swadaya,Jakarta.

Surai. P.F., R.M. Mc Devitt., B.K. Speakeand, N.H.C. Sparks 2000. Carotenoid distribution in issues of the laying hen depending on their dietary supplementation. Proc. Nurt. Soc. 58: 30A.

Tugiyanti, E. dan N. Iriyanti. 2012. kualitas eksternal telur ayam petelur yang mendapat ransum dengan penambahan tepung ikan fermentasi menggunakan isolat prosedur antihistamin. Jurnal aplikasi Teknologi Pangan. 1 
http://journal.ift.or.id./files/e.\%20tu giyanti12-4447.pdf

Tuti, W. 2009. pemanfaatan tepung daun pepaya (carica papaya. 1 less) dalam upaya peningkatan produksi dan kualitas telur ayam sentul. J. agroland 16 (3) : $268-273$,

WeatherupS. T. C., 1980. Description of The Curve Relation Egg Weight and Age of Hen. British Poultry Science 21:511-519.
Widayati.E dan Damayanti, 2000, Aneka Panganan Labu Kuning, Trubus Agrisarana, Surabaya.

Yuliansyah M.F., E. Widodo., I.H. Djunaidi 2015. Pengaruh penambahan sari belimbing wuluh (averrhoa bilimbi 1) sebagai acidifier dalam pakan terhadap kualitas internal telur ayam petelur. Jurnal Nutrisi dan Makanan Ternak. 1(1):19-26. 
